\title{
Exploring the comparison between bilingual and monolingual students' perception of classroom environment
}

\author{
Mohammad Reza Pahlavannezhad \\ Corresponding Author \\ Ferdowsi University of Mashhad \\ Iran
}

\section{Mohammad Heidarypur}

Ferdowsi University of Mashhad

Iran

\section{(c) $\underset{\mathrm{BY}}{(} \bigodot_{\mathrm{ND}}$}

Mohammad Reza Pahlavannezhad: Department of Linguistics, Faculty of Letters, Ferdowsi University of Mashhad, Iran. I E-mail:pahlavan@um.ac.ir

Mohammad Heidarypur: Department of Linguistics, Faculty of Letters, Ferdowsi University of Mashhad, Iran. I E-mail: mohammad.yours@gmail.com 


\section{Abstract}

Bilingualism is a phenomenon, visible in most of the countries all over the world. According to statistics, released in 2017, they make up $42 \%$ of the whole country's population in Iran. The statistical population of this research includes 70 bilinguals and monolinguals, from among BA students of Ferdowsi University of Mashhad. Through random cluster sampling, these individuals were selected, among whom 38 students were monolingual (Farsi), 18 students bilingual (Farsi-Kurdish), and 14 students bilingual (Farsi-Turkish). Perceptions of classroom environment questionnaire (WIHIC) has been used as a research tool. The result shows that all the subscales are significant. In fact, the comprehensiveness variable is significant at $\mathrm{P}<0 / 01$ and support variables are significant at $\mathrm{P}<0 / 001$. To determine the groups' priorities, Post $\mathrm{Hoc}$ Test has been used and the results represented the fact that there is significant difference between the perception of classroom environment in the bilingual groups (Turkish and Kurdish) and monolingual group $(\mathrm{P}<0.001)$, yet there was no significant difference between the two bilingual groups ( $P>0.05)$. Thus, the perception of classroom environment and its subscales in the bilinguals' group has been significantly higher than the monolingual group; however, there is no significant difference between the bilingual groups (Farsi-Kurdish and Farsi- Turkish).

Keywords: perception; bilingualism; monolingualism; Farsi-Kurdish; Farsi-Turkish. 


\section{Introduction}

Bilingualism is a phenomenon visible in most of the countries all over the world and is attributed to the constant use of two languages. Also, those children who use two languages in their daily lives and in different environments, including home, school, etc., are called bilingual (Hartsuiker, 2008). More than half of the world population is bilingual; in United States and Canada, 20 percent of people speak at home in a language other than English. These numbers are higher in urban areas, so the bilinguals make up a large part of population. In educational and schooling bilingualism, the individual learns the other language (the language other than his mother tongue) in the process of formal education and school (Bialystok et al., 2010).

In our country, Iran, also a large part of population is bilingual (e.g. Azeri, Kurdish, Turkish, Bellucci, and Arabic). In recent years, western countries have focused on the psychological aspect of bilingualism and the results of many researches represent the priority of bilingual groups over the monolinguals (Arbabi et al., 2014).

In the field of inspecting bilingualism effects in children's cognitive, social, and educational development, the researchers' perspectives are different. Some of the experts believe in the fact that bilingualism has destructive effects on cognitive factors (Barke et al., 1983). In the course of his education, the bilingual child has difficulty correctly expressing things and this has caused concerns in children and their educational failure. This group of researchers believe that the destructive effects of bilingualism on the child's social and emotional adjustment is greater than its educational success. In the course of their educational career, children, because of not correctly expressing things, are ridiculed by the other children and this results in his mental suffering, hence, anger and depression among these children. Thus, this group of children tries to take distance from the other children and, gradually, they turn into isolated children; this trend affects their personality development negatively. Another group of experts considers the bilingualism as a necessary factor for making better contact with social and family environment and achieving cognitive, emotional, and social development, especially when bilingualism starts in childhood. This group believes in the fact that learning a second language by those children whose mother tongue is a language other than official language is an opportunity to promote cognitive skills (Barahani, 1992). Vygotsky believes that bilingualism results in the promotion of individual's metalinguistic and fluency skills and has positive effects on the individual's childhood and adolescence. Also, bilingualism leads to greater proficiency in the individual's mother tongue and it can even remove its deficiencies (Reymond et al., 2002).

In her investigations, Millet (2000) found that bilingual children living in villages have got lower marks in IQ test, in comparison to monolingual children. These marks have had an ascending trend from 7 to 11 -year-old children, yet in urban areas, there was no significant difference between the monolingual and bilingual children. 
The researchers expected the bilingual subjects to get lower marks in language tasks and almost similar marks in spatial (non-verbal) tasks; further, their research results showed that bilinguals were superior in several tasks, especially those concerned with the manipulation and reorganization of symbols. This unexpected difference between monolingual and bilingual children was also explored in the subsequent studies and the results showed the bilingual children's significant superiority in resolving language issues, based on perceiving such concepts as the difference between form and content, which is called metalinguistic awareness and considered as a non-verbal skill (Bialystok et al., 2010).

According to John Locke, the famous English philosopher, thinking and language are separate entities, yet he considers language as the product of thinking (Stanton, 2006). Thus, according to such viewpoint, language plays a key role and, in fact, language is the mean by which individuals express and interact their thought. Vygotsky (1986) believes in the fact that language and thinking develop separately and, gradually, language turns into a powerful means for thinking. Vygotsky considers making contact and social interaction as the primary role of language and believes that in the process of mental development and parent's relationship with children, language plays a significant role.

Research conducted on the bilinguals' language skills shows that, generally, they have a weaker performance, in comparison to the monolinguals (Bialystok et al., 2010). And the bilinguals are slower and do their tasks with less accuracy. In contrast, the bilinguals have a better performance in controlling and winning over the problems, in comparison to the monolinguals (Bialystok et al., 2010). The research shows that in the development of cognitive skills, the bilinguals' proficiency is different from that of the monolinguals (Grosjean, 2010). The results of research conducted by Gollan and Salmon (2011) show the fact that bilinguals are inflicted with Alzheimer later than the monolinguals; therefore, bilingualism can deter dementia (Gollan et al., 2011).

\section{Review of literature}

Recent research represents the fact that the lower the age of learning a second language, the greater the child's learning and his inclination towards learning a second language. Learning a second language in childhood enhances the brain's functionality in perceptual fields (Bialystok et al., 2010). From a historical perspective, two or more languages were being used in Iran; before Islam, Iranian authorities used Greek language in official and commercial areas, yet they also used their own national language; after Islam, to read Quran, Iranians learned Arabic language alongside Pahlavi language. The translation of Pahlavi books into Arabic confirms this idea (Seddiq, 1972). In Darolfonoon careers, engineering and medical majors were taught in French and, after a while, English and Russian languages were added to the teaching languages of these careers (Safavi, 2004). Using local and city-specific languages is common in media, but using these languages formally and constantly and teaching two or more of these languages in schools has not been operationalized. Even though in current careers, education 
authorities and the authors of textbooks, especially those of the first year of primary school, have always taken the bilingual students into consideration; thus one can say that during the last recent years the program applied in Iran was Structured Immersion Programs. That is, although the languages specific to each ethnicity (Kurdish, Turkish, Arabic, etc.) are not taught in classrooms, teaching Farsi language for the students is matched with their abilities and capacities. Bilingualism introduces Iran as cross bilingual, that is, both languages that the bilinguals know are not among the official languages and, usually, this language is mostly used in intimate environment (family, friends, parties, etc.), rather than formal environment (Zandi, 2002).

In their research, Shams and Imamipoor (2003) found that the learning style of monolingual students is more intuitive, in comparison to the Kurdish bilinguals; the monolingual students, mostly, use the visual learning style, yet the bilingual students, typically, are inclined to the visual learning style.

Cummins (1991) considers perception and cognitive factors as the main factors of conversation and language development. He also believes that individual factors, including motivation, expression, the process of language acquisition, encounter of different languages, and thinking process, are considered as the influential factors of bilingualism cognitive development and, consequently, bilinguals have a higher understanding, in comparison to the monolinguals.

Phindan (2014) argues that children's bilingualism has positive effects on gaining the skills to understand and solve math problems and controlling the languages processes. Further, he states that bilingualism has a positive effect on cognitive capabilities, when the bilingual achieves a certain level of language development in the second language.

In a research, Kesaian (2015) found that the bilingual migrants' performance in education system has been better than the monolinguals and considered the bilinguals' fluid, superior conceptual thinking as the cause of this difference and different mental capabilities. Phindan (2014) contends that bilinguals' cognitive development is the result of divergent thinking, flexibility, and fluid intelligence.

\section{Research method}

The statistical population of the current research includes all the bachelor students of Ferdowsi University of Mashhad studying Persian Literature in (2017-2018) academic year. From among the research statistical population, a sample including 70 students was selected, using random cluster sampling, among which 38 students are monolingual (Farsi); 18 students, bilingual (Farsi-Kurdish); and 14 students, bilingual (Farsi-Turkish). The research questionnaires were distributed among the students. Perceptions of classroom environment questionnaire (WIHIC) has been used as a research tool for measuring and analyzing the perception rate of bilingual or multilingual and monolingual students. The "What Is Happening In this Class" 
questionnaire, designed by Fraser, Fisher, and McRobbie (1996), has been used in this research. This questionnaire has been codified, including 56 questions and 7 subscales, regarding the students' dependence, teachers and professors' support, learners' involvement, research, task orientation, cooperation, and justice. A research by Nikdel et al. (2013) showed that this questionnaire has great internal consistency and the Cronbach's Alpha Coefficients, for its subscales, has been between 0.79-0.90.

\section{Data analysis}

To analyze the data, in the first section of the current research, the research characteristics and research hypothesis testing are explained.

\section{TABLE 1}

Descriptive data for perception of classroom environment variables in the monolinguals' group

\begin{tabular}{|c|c|c|c|c|c|c|c|c|}
\hline $\begin{array}{l}\text { STATISTICAL } \\
\text { CHARAC- } \\
\text { TERISTICS }\end{array}$ & $\begin{array}{l}\text { PERCEPTION } \\
\text { OF CLASSROOM } \\
\text { ENVIRONMENT }\end{array}$ & $\begin{array}{l}\text { COMPREHEN- } \\
\text { SIVENESS }\end{array}$ & SUPPORT & $\begin{array}{l}\text { COLLABO- } \\
\text { RATION }\end{array}$ & $\begin{array}{l}\text { EXPLO- } \\
\text { RATION }\end{array}$ & $\begin{array}{l}\text { ORIEN- } \\
\text { TATION }\end{array}$ & $\begin{array}{l}\text { COOPER- } \\
\text { ATION }\end{array}$ & BALANCE \\
\hline Number & 38 & 38 & 38 & 38 & 38 & 38 & 38 & 38 \\
\hline Minimum & 107 & 11 & 17 & 12 & 18 & 14 & 10 & 12 \\
\hline Maximum & 164 & 31 & 31 & 31 & 37 & 28 & 29 & 28 \\
\hline Average & 140.73 & 19.84 & 19.39 & 21.81 & 27.78 & 19.10 & 16.31 & 16.47 \\
\hline $\begin{array}{l}\text { Standard } \\
\text { deviation }\end{array}$ & 12.31 & 3.88 & 5.64 & 5.19 & 3.72 & 3.01 & 3.74 & 5 \\
\hline Variance & 151.6 & 15.05 & 31.92 & 27.09 & 13.90 & 9.07 & 14.06 & 25.01 \\
\hline
\end{tabular}

\section{TABLE 2}

Descriptive data for perception of classroom environment variables in the bilinguals' group (Farsi-Kurdish)

\begin{tabular}{|c|c|c|c|c|c|c|c|c|}
\hline $\begin{array}{l}\text { STATISTICAL } \\
\text { CHARAC- } \\
\text { TERISTICS }\end{array}$ & $\begin{array}{l}\text { PERCEPTION } \\
\text { OF CLASSROOM } \\
\text { ENVIRONMENT }\end{array}$ & $\begin{array}{l}\text { COMPREHEN- } \\
\text { SIVENESS }\end{array}$ & SUPPORT & $\begin{array}{l}\text { COLLABO- } \\
\text { RATION }\end{array}$ & $\begin{array}{l}\text { EXPLO- } \\
\text { RATION }\end{array}$ & $\begin{array}{l}\text { ORIEN- } \\
\text { TATION }\end{array}$ & $\begin{array}{l}\text { COOPER- } \\
\text { ATION }\end{array}$ & BALANCE \\
\hline Number & 18 & 18 & 18 & 18 & 18 & 18 & 18 & 18 \\
\hline Minimum & 149 & 24 & 16 & 11 & 13 & 12 & 15 & 10 \\
\hline Maximum & 208 & 37 & 27 & 32 & 39 & 39 & 28 & 37 \\
\hline Average & 180.77 & 30.22 & 22.5 & 26.16 & 31.22 & 27.88 & 21.35 & $22 / 66$ \\
\hline $\begin{array}{l}\text { Standard } \\
\text { deviation }\end{array}$ & 17.67 & 3.76 & 3.01 & 8.19 & 7.12 & 7.45 & 3.38 & $6 / 51$ \\
\hline Variance & 312.41 & 14.18 & 9.08 & 6.08 & 5.77 & 5.72 & 11.47 & $4 / 47$ \\
\hline
\end{tabular}




\section{TABLE 3}

Descriptive data for perception of classroom environment variables in the bilinguals' group (Farsi-Turkish)

\begin{tabular}{|c|c|c|c|c|c|c|c|c|}
\hline $\begin{array}{l}\text { STATISTICAL } \\
\text { CHARAC- } \\
\text { TERISTICS }\end{array}$ & $\begin{array}{l}\text { PERCEPTION } \\
\text { OF CLASSROOM } \\
\text { ENVIRONMENT }\end{array}$ & $\begin{array}{l}\text { COMPREHEN- } \\
\text { SIVENESS }\end{array}$ & SUPPORT & $\begin{array}{l}\text { COLLABO- } \\
\text { RATION }\end{array}$ & $\begin{array}{l}\text { EXPLO- } \\
\text { RATION }\end{array}$ & $\begin{array}{l}\text { ORIEN- } \\
\text { TATION }\end{array}$ & $\begin{array}{l}\text { COOPER- } \\
\text { ATION }\end{array}$ & BALANCE \\
\hline Number & 14 & 14 & 14 & 14 & 14 & 14 & 14 & 14 \\
\hline Minimum & 152 & 20 & 19 & 16 & 27 & 14 & 15 & 16 \\
\hline Maximum & 209 & 37 & 36 & 37 & 39 & 39 & 28 & 25 \\
\hline Average & $186 / 28$ & $25 / 64$ & $27 / 04$ & $30 / 71$ & 35 & 25 & $21 / 35$ & $21 / 5$ \\
\hline $\begin{array}{l}\text { Standard } \\
\text { deviation }\end{array}$ & $16 / 69$ & $8 / 15$ & $4 / 79$ & $4 / 74$ & $3 / 39$ & 7/09 & $3 / 38$ & $2 / 13$ \\
\hline Variance & $278 / 68$ & $6 / 55$ & $22 / 95$ & $22 / 52$ & $11 / 53$ & $5 / 30$ & $11 / 47$ & $4 / 57$ \\
\hline
\end{tabular}

In the following section, to test the research hypothesis, MANOVA has been used, the results of which are presented in the following table.

The results of Kolmogorov-Smirnov test showed that this test is not significant for this research variables in research groups $(P>0.05)$, thus it can be inferred that data distribution is normal and one of the assumptions of Multivariate Analysis of Variance has been observed.

The next assumption, considered for conducting Multivariate Analysis of Variance, is Levene Test, which was not significant for this research ( $P>0.05)$; this represents the fact that the variance and covariance in this research variables are equal, so we can use the Multivariate Analysis of Variance. For the rest, we will inferentially explore the hypotheses, and to test the primary hypothesis, the Multivariate Analysis of Variance was used; the overall index of Wilks's Lambda showed that the effects of group on the linear combination of multiple variables was significant (F-10.412, P<0.001, R2-0.684).

Therefore, the research hypothesis is confirmed and this represents the fact that bilingualism results in higher perception of classroom environment. However, to test the secondary hypotheses and determine which variable has changed in which group, the results of these analyses will be presented in the table 4.

The results represent the fact that all the subscales are significant. In fact, the comprehensiveness variable is significant at $\mathrm{P}<0 / 01$ and support, collaboration, exploration, orientation, cooperation, and balance variables are significant at $\mathrm{P}<0 / 001$.

In the following sections, to determine which groups are superior in these subscales, the post hoc Bonferroni test was conducted and the results showed that there is significant difference between the perception of classroom environment in the bilingual groups (Turkish 


\section{TABLE 4}

The results of Multivariate Analysis of Variance

\begin{tabular}{ccccccc} 
VARIABLE & $\begin{array}{c}\text { SUM OF } \\
\text { SQUARES }\end{array}$ & $\begin{array}{c}\text { DEGREES OF } \\
\text { FREEDOM }\end{array}$ & $\begin{array}{c}\text { MEAN OF } \\
\text { SQUARES }\end{array}$ & $F$ & $\begin{array}{c}\text { LEVEL OF } \\
\text { SIGNIFICANCE }\end{array}$ & $\begin{array}{c}\text { ETA } \\
\text { COEFFICIENT }\end{array}$ \\
\hline Comprehensiveness & $18 / 364$ & 1 & $18 / 364$ & $9 / 678$ & $0 / 007$ & $0 / 392$ \\
\hline Support & $41 / 3$ & 1 & $41 / 3$ & $23 / 179$ & $0 / 000$ & $0 / 607$ \\
\hline Collaboration & $50 / 572$ & 1 & $50 / 572$ & $31 / 027$ & $0 / 000$ & $0 / 674$ \\
\hline Exploration & $45 / 46$ & 1 & $45 / 46$ & $25 / 12$ & $0 / 000$ & $0 / 621$ \\
\hline Orientation & $36 / 53$ & 1 & $36 / 53$ & $18 / 25$ & $0 / 000$ & $0 / 547$ \\
\hline Cooperation & $25 / 42$ & 1 & $25 / 42$ & $13 / 81$ & $0 / 000$ & $0 / 431$ \\
\hline Balance & $31 / 12$ & 1 & $31 / 12$ & $15 / 47$ & $0 / 000$ & $0 / 482$ \\
\hline
\end{tabular}

and Kurdish) and the monolingual group ( $\mathrm{P}<0.001)$, yet there was no significant difference between the two bilingual groups (P>0.05). Therefore, it can be inferred that the perception of classroom environment and its subscales in the bilingual groups is significantly higher than the monolingual group, yet there is no significant difference between the two bilingual groups (Farsi-Kurdish and Farsi-Turkish).

\section{Findings, discussion, and conclusion}

The current research was conducted, aiming at the exploration of perception of classroom environment between two groups of students. The obtained results indicate the fact that there is significant difference between the monolingual and bilingual students' perception of classroom environment. That is, bilingual students have had a higher perception, in comparison to the other group. Also regarding the subscales of perception of classroom environment, bilingual students had a better performance and perception of classroom environment, regarding such components as students' dependence and teachers' support, task orientation and cooperation, students' involvement, research, and justice.

The obtained research result is consistent with the research conducted by Ahmadpoor, Bialystok, Reymond, Salvatierra and Rosselli, Carlson and Meltzoff. Also we found that bilingualism can affect the quality and rate of perception of classroom environment. Ahmadpoor (1993) compared the perception and performance of two groups of male and female bilingual and monolingual students in learning English vocabularies and found that bilingual students had a better performance and perception, in comparison to the monolinguals, which is consistent with the result of current research. In another research, Ahmadpoor (1993) explored the effects of bilingualism on the students' learning trend and found that there is significant differ- 
ence between the experiment group (bilinguals) and control group (monolingual), regarding their involvement in group working, communicating with others and taking responsibility, cooperating with others, and making friends. The results of research by Bialystok (2008), exploring the relationship between bilingualism and cognitive factors, show that bilingualism is directly correlated to such factors as problem solving, creative thinking, divergent thinking skills, independence, concept formation, and cognitive flexibility. Another research by Salvatierra and Rosselli (2011), comparing the monolingual and bilingual groups, using Simon test, represents the fact that bilinguals had a better performance and perception, in comparison to the monolinguals; this also proves true in the elderly group (the average age of 64 years). Also, the result of research by Carlson and Meltzoff (2008), comparing the results of conducting a set of tests on both the monolingual and bilingual groups, represents that, in most cases, the performance of bilinguals has been higher than monolinguals. Based on all these essays, one can conclude that there is significant difference between the bilingual and monolingual students' perception rate of classroom environment.

In his research, Barahani (1992) documents that bilingualism results in having problems understanding the precise meaning of messages and written and oral information and potential misunderstanding in social interaction; nevertheless, if the bilingual speaker is equal to the monolingual speakers socially and economically, bilingualism can lead to the speaker's perceptual and intellectual richness, which is consistent with comprehensiveness and cooperation subscales in the current research.

The result of research conducted by Raymond et al. (2002) shows that bilingualism leads to the development of individuals' cognitive abilities, metalinguistic, and fluency skills and has more positive effects in childhood, rather than adulthood. Further, it can promote linguistic skills and remove its deficiencies. The result of this research, also, is consistent with the orientation and exploration subscales in current research and bilingualism is influential in the individuals' rate of orientation, precision, and exploration.

In the research, Bialystok and Viswanathan (2009), exploring inhibition and flexibility control in the two bilingual and monolingual groups, found that both groups have performed almost equally and one can state that, based on the research result, the subscales of balance, support, and collaboration have been similar for the bilingual groups and different from the monolingual one.

The result of this research confirms the results obtained by Martin-Rhee and Bialystok (2008) and Prior and Mac Whinney (2010), who explored two groups of bilingual and monolingual speakers and found the superiority of bilinguals.

In this research, the bilinguals have thorough understanding of both Farsi-Turkish and Farsi-Kurdish languages and, regarding the obtained result, bilingualism has been observed as a positive phenomenon for the bilinguals and the cause of their cognitive superiority over 
the monolinguals. The current research, just like many other research in the field of humanities, has limitations and obstacles, including the lack of necessary resources and cooperation from some schools and teachers for filling the questionnaires.

\section{References}

Ahmadpoor, Naser, 1993: Exploring the Effects of bilingualism on the Learning Process of First Grade Students of Elementary Schools in Lorestan. M. A. Thesis, Tarbiat Moallem University, Tehran.

Arbabi, Sara, Shahla Sharifl and Ali MashHadi, 2014: "The Effects of Bilingualism on Cognition, The Study of Azeri-Farsi Bilinguals", Foreign Language Research Journal 3 (1), 1-18.

BAKER, Colin, 2011: Foundations of bilingual education and bilingualism, Clevedon Hall: Multilingual Matters.

Barahanl, Mohammadtaghi, 1992: "Cognitive Consequences of Bilingualism”, Tehran, Seminar on Exploring the Different Aspects of Bilingualism, Ministry of Education, 92-97.

Barke, Ethel, and Williams PerRY, 1983: "A further study of the comparative intelligence of children in certain bilingual and monoglot schools in South Wales", British Journal of Educational Psychology 8, 63-77.

Bialystok, Ellen, Fergus Craik and Gigi Luk, 2008: "Lexical access in bilinguals' effects of vocabulary size and executive control", Journal of Neurolinguistics 21, 522-538.

Bialystok, Ellen, Gigi Luk and Kathleen F. Peets, 2010: "Receptive vocabulary differences in monolingual and bilingual adults", Biling. Lang. Cogn. 13, 525-531.

Bialystok, Ellen, and Mythili Viswanathan, 2009: "Components of executive control with advantages for bilingual children in two cultures", Cognition 112 (3), 494-500.

BIALYSTOK, Ellen, 2008: "Second-language acquisition and bilingualism at an early age and the impact on early cognitive development", Encyclopedia on Early Childhood Development 11 (3), 4-8.

Carlson, Stephanie M., and Andrew N. Meltzoff, 2008: "Bilingual experience and executive functioning in young children”, Developmental Science 11 (2), 282-298.

Cummins, Jim, 1991: "Interdependence of First- and Second-Language Proficiency in Bilingual Children" in E. BIALYstock (ed.): Language Processing in Bilingual Children, Cambridge: Cambridge University Press, 70-89. 
DIAz, Rafael, and Kathy A. PADILLA, 1985: "The self-regulatory speech of bilingual preschoolers", paper presented at the 1985 meeting of the Society for Research in Child Development, Toronto, Canada.

Fraser, Barry J., Darrell L. Fisher and Campbell J. McRobbie, 1996: "Development, validation, and use of personal and class forms of a new classroom environment instrument", paper presented at the annual meeting of the American Educational Research Association, New York.

Gollan, Tamar H., David P. Salmon, Rosa I. Montoya and Douglas R. Galasko, 2011: "Degree of bilingualism predicts age of diagnosis of Alzheimer's disease in low-education but not in highly educated Hispanics", Neuropsychologia 49, 3826-3830.

Grosjean, F., 2010: Bilingual Life and Reality, Harvard University Press.

HARTSUIKER, Robert J., 2008: "Bilingualism: functional and neural perspectives", Acta Psychologica $128,413-415$.

KASAIAN, Seyed Ahmad, 2015: "Language Learners Attrition Rate, A Case Study in Ili Timothy Stanton, 2006, Locke and the politics and theology of toleration", Political Studies 54, 84-102.

MıLLet, Katherine Ruth Gordon, 2010: The Cognitive Effects of Bilingualism: Does Knowing Two Languages Impact Children's Ability to Reason about Mental States?

KHosHroo, Vahid, 1996: "Identifying the Effects of Bilingualism on Academic Progress".

Maroofl, Yahya, and Ismail Mohammadnia, 2011: "Bilingualism and Its Relationship with Critical Thinking Skills", Journal of Educational Innovation 45, 45-60.

Martin-Rhee, Michelle M., and Ellen Bialystok, 2008: "The development of two types of inhibitory control in monolingual and bilingual children", Bilingualism: Language and Cognition $11(1), 81-93$.

Nikdel, Fariborz, Parvin Kadivar, Mahdi Arabzadeh and Javad Kavousian, 2013: "Possible involvement of academic emotions in the relationship between goals and strategies for the development of self-learning: a structural model", Journal of Teaching and Learning 5 (2), 113-136.

PeAL, Elizabeth, and Wallace E. Lambert, 1962: "The relation of bilingualism to intelligence", Psychology Monogr. 76, 1-23.

Phindane, Pule, 2014: "Reading Skills Acquisition in English: A Comparison of Monolingualism and Bilingualism in Foundation Phase”, Journal of Psychology 5 (1), 85-96. 
Prior, Anat, and Brian MacWhinney, 2010: "A bilingual advantage in task switching”, Bilingualism, Language and Cognition 13 (2), 253-262.

RaYmond, T. Albert, Rachel E. Albert and Jenny Radsma, 2002: "Relationships among bilingualism, critical thinking ability, and critical thinking disposition", Journal of Professional Nursing 18 (4), 220-229.

SAfavi, Amanollah, 2004: Iran's History of Education, Tehran: Roshd Publication, Tehran: Iran.

Salvatierra, Jydy Lee, and Monica Rosselli, 2011: "The effect of bilingualism and age on inhibitory control", International Journal of Bilingualism 15 (1), 26-37.

SEddiQ, Isa, 1972: A Cultural History of Iran, Tehran University, Tehran, Iran.

Seperr, Vahid, 2004: "Education and the Necessity of Meeting Bilingual Children's Requirements", The Proceedings of Education Conference, Problems and Solutions, Sanandaj, 196-212.

Shams Esfandabad, Hassan, and Suzan Imamipour, 2003: "The study of learning styles in students a bilingual school and its relationship to academic achievement and gender", Journal of Educational Innovations 5, 2-11.

Stanton, Timothy, 2006: "Locke and the Politics and Theology of Toleration", Political Studies $54,84-102$.

Vygotsky, Lev S., 1986: “Thought and Language”, Cambridge, MA: MIT Press.

ZAnDI, Bahman, 2002: Language Learning, Tehran: Samt Publication. 